\title{
Species-specific impacts of grazing amphipods in an eelgrass-bed community
}

\author{
J. Emmett Duffy* ${ }^{*}$ Annie M. Harvilicz \\ School of Marine Science and Virginia Institute of Marine Science, The College of William and Mary, Gloucester Point, \\ Virginia 23062-1346, USA
}

\begin{abstract}
Small, grazing invertebrates often benefit seagrasses by cropping their epiphytic algal competitors. Yet predictive relations between grazer abundance and seagrass performance are elusive, in significant part because of poorly understood diversity in mesograzer feeding biology. We conducted experiments in eelgrass Zostera marina microcosms to explore how differences in feeding between 2 common grazing amphipod taxa affected accumulation and species composition of epiphytes on eelgrass, as well as amphipod population growth, competition and production, over a 4-week period in summer. Gammarus mucronatus and ampithoids (a mixture of Cymadusa compta and Ampithoe longimana) were stocked, singly and in combination, along with a grazer-free control treatment. Amphipod population growth rates indicated that the 2 taxa competed for a common limiting resource, presumably periphyton, which was essentially eliminated in all grazer treatments. Final abundances of both amphipod taxa were 53 to $68 \%$ lower in treatments where the other grazer was present than in single-species grazer treatments. A common carrying capacity was also indicated by the nearly identical final biomass of amphipods across treatments, despite 2-fold variation in initial amphipod densities. These results support the hypothesis that the 2 amphipod taxa are roughly equivalent in terms of resource requirements and production rates. Despite this equivalence, subtle differences in diet breadth between amphipod taxa translated into substantial differences in biomass and composition of the fouling assemblage among treatments. Whereas grazer-free eelgrass became heavily fouled with periphyton and tunicates, eelgrass exposed to G. mucronatus alone was overgrown by the red alga Polysiphonia harveyi, which reached a biomass equal to the total fouling mass of grazer-free controls. P. harveyi was nearly absent from all other treatments. In contrast, eelgrass with ampithoids was virtually devoid of all fouling material. Thus, similar mesograzer species can have markedly different impacts on fouling assemblages, and these occur despite strong similarity in grazer energetics and primary food sources. Our results may help to reconcile evidence of diet overlap and diffuse competition among mesograzer species with the different feeding preferences and community impacts shown for several mesograzers in experimental studies.
\end{abstract}

KEY WORDS: Amphipods $\cdot$ Ampithoe longimana $\cdot$ Community structure $\cdot$ Competition $\cdot$ Cymadusa compta · Gammarus mucronatus · Grazing · Mesograzers · Resource limitation · Zostera marina

Resale or republication not permitted without written consent of the publisher

\section{INTRODUCTION}

Benthic plants throughout the world's coastal regions harbor populations, often very dense, of small grazing and detritivorous invertebrates, primarily amphipod and

*E-mail: jeduffy@vims.edu isopod crustaceans and gastropod molluscs. In many vegetated marine and estuarine ecosystems these mesograzers are the dominant primary consumers (Orth \& van Montfrans 1984, Brawley 1992). Estimates based on production and consumption rates, as well as a limited number of experimental studies, suggest that such mesograzers are pivotal both in transfer of primary production to higher trophic levels, including fisheries (Kikuchi 
1974, Klumpp et al. 1989, Edgar \& Shaw 1995, Taylor 1998), and in structuring the assemblages of plants on which they feed (Orth \& van Montfrans 1984, Jernakoff et al. 1996, Duffy \& Hay 2000, Duffy et al. 2001). In some seagrass systems, in particular, mesograzers may be important ecological engineers (sensu Jones et al. 1994) in that their preferential grazing on fast-growing epiphytic algae releases macrophytes from competition (Robertson \& Mann 1982, Hootsmans \& Vermaat 1985, Howard \& Short 1986, Neckles et al. 1993), allowing macrophytes and the ecologically and economically important communities that depend on them to flourish. Despite such evidence, however, general conclusions about the role of grazing in ecology of seagrass systems remain elusive (Orth 1992, Jernakoff et al. 1996, Valentine \& Heck 1999).

Among several contributors to the continuing uncertainty about the role of grazing in seagrass dynamics, 2 important ones are our rudimentary understanding of mesograzer feeding biology at the species level (Jernakoff et al. 1996), and the paucity of rigorous experimental studies of their impacts on plant populations and community structure (Duffy \& Hay 2000, Duffy et al. 2001). Largely because of general similarity in body size and challenging taxonomy, it has been common to lump mesograzers into a homogeneous functional group believed to feed relatively non-specifically on microalgae and detritus (Steneck \& Watling 1982, Edgar 1990a, Bell 1991). This view is supported directly by some evidence from gut contents and feeding assays (Nagle 1968, Nelson 1979, Jernakoff et al. 1996) and indirectly by experiments showing a degree of functional equivalence among co-occurring mesograzer species. In particular, experimental manipulations of mesograzer abundance and species composition in the field (Edgar 1990a, Edgar \& Aoki 1993) resulted in rapid compensatory responses of the mesograzer assemblage, consistent with diffuse competition and limitation by a common resource, presumably periphyton production (the 'production ceiling' hypothesis, Edgar 1993). This evidence for functional equivalence of mesograzers stands in contrast to experimental studies showing significant variation among mesograzer species in feeding preferences or diet range (Zimmerman et al. 1979, Kitting 1984, Duffy 1990, Duffy \& Hay 1994, 2000), and in impacts on biomass and species composition of the plant assemblage (Duffy 1990, Jernakoff \& Nielsen 1997, Duffy \& Hay 2000, Duffy et al. 2001). Because evidence for mesograzer functional equivalence versus diversity often have come from studies using different methods, the potential importance of mesograzer diversity to benthic plant dynamics remains unresolved.

In this study we used microcosm experiments to test the functional equivalence, in terms of both resource use and impacts on the plant assemblage, of 2 of the dominant grazing amphipod taxa in vegetated habitats along much of the east coast of North America. We stocked outdoor eelgrass Zostera marina microcosms with Gammarus mucronatus and ampithoid amphipods (a mixture of the morphologically similar species Cymadusa compta and Ampithoe longimana) singly and in combination, and followed the development of the fouling assemblage on eelgrass. We asked the following questions: (1) Do the 2 amphipod taxa compete for resources? And (2) do they differentially affect the species composition and biomass of the eelgrass fouling community? We show that, whereas the 2 amphipod taxa feed on a similar spectrum of plants and demonstrably compete for the limiting resource of periphyton, subtle differences in their feeding preferences are magnified into substantial divergence in biomass and species composition among fouling assemblages.

\section{MATERIALS AND METHODS}

Laboratory feeding assay. As an initial assessment of whether feeding preferences of Gammarus mucronatus and the common ampithoid Cymadusa compta differed, we conducted a laboratory choice assay measuring feeding on eelgrass and several macroalgal epiphytes and drift algae common in local eelgrass beds during summer. These were Zostera marina (live green), Z. marina (senescent brown), the red algae Agardhiella subulata and Polysiphonia harveyi, and the green algae Ulva sp., Enteromorpha sp. and Blidingia (formerly Enteromorpha) sp. One small piece of each of the 7 food types was blotted dry, weighed and placed in a shallow bowl along with either 3 C. compta or 6 G. mucronatus, corresponding to approximately equal grazer biomasses at the time of the experiment. After $\sim 72 \mathrm{~h}$, the pieces were removed, blotted and weighed again. Twenty replicate bowls were set up for each species, and 20 bowls with plant pieces but no grazers were run simultaneously to estimate autogenic mass changes unrelated to grazing. We tested whether the 2 amphipod species differed in grazing rates on each plant type using separate 2 sample $t$-tests, with experiment-wise error rate controlled using the sequential Bonferroni procedure (Rice 1989).

Microcosm experiment. We conducted a microcosm experiment in summer 1998 to assess the degree of functional equivalency between 2 amphipod taxa, Gammarus mucronatus and ampithoid amphipods, that are dominant components of the epifauna in vegetated coastal habitats along much of the east and Gulf coasts of the USA (Nelson 1979, 1980, Schneider \& Mann 1991, Duffy et al. 2001). Our experiment tested 
(1) the existence of competition between these 2 amphipod taxa, as evidenced in reduced population growth rates in the presence of the other grazer, and (2) impacts of the 2 grazer taxa, alone and in combination, on the dominant sessile organisms of local seagrass beds in summer, namely eelgrass, its micro- and macroepiphytes, and the tunicate Molgula manhattensis. Two morphologically very similar species of ampithoid amphipods, Cymadusa compta and Ampithoe longimana, are present in eelgrass beds in our area. Because it was logistically prohibitive to identify individual live amphipods microscopically before stocking them in our experiment, these 2 species were introduced to our ampithoid treatments in unknown proportions. Hence, by necessity, we have pooled these 2 species as 'ampithoids' in our analyses and discussion.

The experiment was conducted in a series of thirtyfive, 221 opaque white plastic microcosms located at the Virginia Institute of Marine Science. The outdoor microcosms were supplied with a constant flow of sand-filtered estuarine water from the adjacent York River and were exposed to ambient conditions of light, temperature and weather. A $250 \mu \mathrm{m}$ mesh filter bag was placed under each container's inflow valve to minimize colonization of the containers by unwanted grazers (larvae of sessile invertebrates evidently passed easily through the filter as they consistently colonized our experimental chambers, sometimes in large numbers). Water flowed out of each container through 4 holes of $4.5 \mathrm{~cm}$ in diameter and covered with $1 \mathrm{~mm}$ plastic mesh.

The experiment included 5 treatments: (1) a grazerfree control, (2) Gammarus mucronatus alone $\left(\mathrm{N}_{0}=35\right.$ amphipods), (3) ampithoids alone $\left(\mathrm{N}_{0}=35\right)$, (4) both taxa at 'low' density $\left(\mathrm{N}_{0}=18\right.$ amphipods of each taxon, such that combined abundance is equal to that of the single-taxon treatments), and (5) both taxa at 'high' density $\left(\mathrm{N}_{0}=35\right.$ amphipods of each taxon, such that abundance of each species individually equals its abundance in the corresponding single-taxon treatment). Each treatment was replicated in 7 independent microcosms in a randomized-block design, with all treatments in a given block established on the same day, stocked from the same collection of eelgrass and grazers, and placed in physical proximity to each other within the microcosm array. Initial amphipod densities were near the low end of the range we have measured in local eelgrass beds in summer.

We initiated the experiment in July 1998, when we planted 50 eelgrass shoots in each container, simulating a natural eelgrass density in Chesapeake Bay of $\sim 1000$ shoots $\mathrm{m}^{-2}$ (Orth \& Moore 1986). Eelgrass in our area is generally very clean of epiphytes for much of the year, especially in early summer when our experiment was initiated. For this reason, and because we chose the cleanest, healthiest eelgrass shoots for stocking the experiment, there were virtually no visible epiphytes on the eelgrass when we began the experiment. Thus, we made no effort to clean the shoots or measure initial epiphyte load. A few days after planting, we stocked the microcosms with grazers.

Measurement of treatment effects. At 2 and $4 \mathrm{wk}$ after amphipods were added to the microcosms, we collected 2 haphazardly selected eelgrass blades from each microcosm and pooled them for analysis of epiphytic chlorophyll as a proxy for epiphyte biomass. All fouling material was scraped from the blades using the edge of a glass microscope slide and vacuum-filtered onto a glass fiber filter. The filter containing the epiphytic material was frozen to disrupt algal cell walls, then extracted with $20 \mathrm{ml}$ of methanol/acetone/deionized water $(45: 45: 10)$ at $-20^{\circ} \mathrm{C}$ for $24 \mathrm{~h}$. After the extract was filtered, chlorophyll a ( $\mathrm{chl}$ a) concentration was measured on a Milton Roy 1001 spectrophotometer (Milton Roy Co., Rochester, NY) according to the methods of Parsons et al. (1984). The area of each of the cleaned blades was then measured, either manually as the product of length times width or using a Li-Cor 3100 area meter (Li-Cor, Lincoln, NE), and epiphytic chlorophyll concentrations were normalized to unit blade surface area by dividing the measured chlorophyll concentration by the area of blade surface sampled.

The experiment was terminated in each block $4 \mathrm{wk}$ after grazers had been added. At this time, the second epiphytic chlorophyll sample was taken, and an additional 2 blades were removed from each tank to measure total fouling accumulation. Fouling material was scraped from the latter blades onto a preweighed paper filter, dried at $60^{\circ} \mathrm{C}$ for $48 \mathrm{~h}$ and weighed. After samples for fouling material and epiphytic chlorophyll had been collected, all remaining eelgrass was uprooted, shaken gently in the water to dislodge grazers, then placed in a plastic bag and frozen. After eelgrass was removed, the remaining water in the tank was decanted through a $500 \mu \mathrm{m}$ mesh sieve. Sieve contents, including grazers, were rinsed with running York River water, drained and preserved in $70 \%$ ethanol. Eelgrass samples were then separated into above- and below-ground portions, and any attached macroalgae, larger sessile invertebrates, and associated grazers were also separated and identified. Above- and belowground eelgrass tissues, algae and sessile invertebrates were dried for several days at $60^{\circ} \mathrm{C}$ and weighed separately. Any grazers present were added to the ethanol-preserved sample from that microcosm.

Final abundance, population size structure and biomass of amphipods were estimated using the method of Edgar (1990b): amphipods were sorted into size classes by rinsing the sample through a nested series of 
sedimentological sieves $(5.6,4.0,2.8,2.0,1.4,1.0,0.71$ and $0.50 \mathrm{~mm}$ ), amphipods retained on each sieve were counted, and their ash-free dry mass (AFDM) was calculated for each sieve size listed above using conversions in Edgar (1990b); these are 14.7, 5.8, 2.3, 0.91, $0.26,0.143,0.058$ and $0.023 \mathrm{mg}$ ind..$^{-1}$, respectively.

To compare amphipod abundance and biomass in our experiment with field values (see next section), we normalized abundances to the area of available habitat surface, including both eelgrass leaves and container walls in the microcosms. This is based on (1) the assumption that amphipods are limited either directly by habitat availability or indirectly by surface area available for growth of their periphyton food, and (2) our observations of both amphipods and their epiphytic food source using the wall surfaces as substratum during the experiment. We estimated that the exposed wall area within a container was $2940 \mathrm{~cm}^{2}$, and added this to eelgrass surface area estimated by converting dry mass values using the equation from Parker et al. (2001): dry mass $(g)=429$ surface area $\left(\mathrm{cm}^{2}\right)$. Because the container walls are artificial habitats, we also calculated amphipod biomass estimates standardized to area of eelgrass blades alone and to bottom area, for comparison with field data and previous studies.

Field sampling. To assess how amphipod abundance in our microcosm experiment compared with that in the field, we sampled epifauna from an eelgrass bed at Goodwin Islands $\left(37^{\circ} 12^{\prime} \mathrm{N}, 76^{\circ} 23^{\prime} \mathrm{W}\right)$ in the Lower York River, Virginia, USA, during October 1999. We collected 9 replicate samples of eelgrass with associated animals from the offshore margin of the bed, where the shallow depth $(<0.5 \mathrm{~m}$ at low tide) was comparable with that of our microcosms. Each sample was collected from a bottom area of $0.0156 \mathrm{~m}^{2}$ using a plexiglass core tube, $11.7 \mathrm{~cm}$ inside diameter, with a $250 \mu \mathrm{m}$ mesh bag secured over its top end. The tube was placed over eelgrass blades with their associated fauna, blades were cut at the base with scissors, and the bottom of the tube was closed off. The tube was then inverted and its contents, including grass, epifauna and any associated algae, were rinsed into the bag and frozen. In the laboratory, the sample contents were separated by taxon, and eelgrass was dried for several days at $60^{\circ} \mathrm{C}$ and weighed. All mobile epifaunal species were identified, counted and sized, and their biomass was estimated as described above. Animal abundance per unit surface area was estimated by converting the measured seagrass biomass to surface area using the conversion factor mentioned above.

Data analysis. Before statistical hypothesis testing, variance heterogeneity among treatments was tested using Cochran's test and variance was transformed by $\log (\mathrm{x})$ where necessary. Results of the microcosm ex- periment were analyzed initially using randomizedblock ANOVAs in which the different grazer treatments were considered fixed factors. All analyses used the block $\times$ treatment interaction mean square as the denominator in the F-tests (Newman et al. 1997). In cases where the block effect was clearly non-significant $(p>0.25)$, we ignored the blocking factor and reanalyzed the data with a simple 1- or 2-factor ANOVA, following recommendations of Winer et al. (1991). Where the $F$-test was significant, we identified differences among treatments with Ryan's Q-test (Day \& Quinn 1989).

For several response variables, both mean and variance in certain treatments were zero or near zero (see 'Results'), and variance heterogeneity could not be corrected by transformation. In these cases we tested differences among treatments using Friedman's test, a nonparametric analog of the ANOVA for randomized block designs (Sokal \& Rohlf 1981). Because we know of no nonparametric multiple comparison test that accommodates a blocked design and is suitable for use with heterogeneous variances (Day \& Quinn 1989), we did not follow Friedman's test with multiple comparisons. Nevertheless, the general pattern was clear in all such cases (see 'Results').

\section{RESULTS}

\section{Laboratory feeding assay}

Gammarus mucronatus and Cymadusa compta consumed nearly identical amounts of all species offered except Polysiphonia harveyi (Fig. 1). The latter alga was heavily grazed by $C$. compta but essentially untouched by G. mucronatus. Bonferroni-corrected $t$-tests revealed that $P$. harveyi was the only food offered that was differentially grazed by the 2 amphipod species.

\section{Grazer population growth and competition}

Populations of both amphipod taxa grew rapidly during the $4 \mathrm{wk}$ of the experiment, total abundances increasing by well over an order of magnitude in all treatments (Figs 2A \& 3). Two lines of evidence suggest that Gammarus mucronatus and ampithoids reached a common carrying capacity set by resource availability during the experiment and that interspecific competition for this resource further limited their respective population growth rates. First, total amphipod biomass at the end of the experiment was remarkably similar across all 4 treatments containing amphipods (Fig. 2B, Table 1), despite starting abundance (and presumably biomass) in the 'both high' treatment 


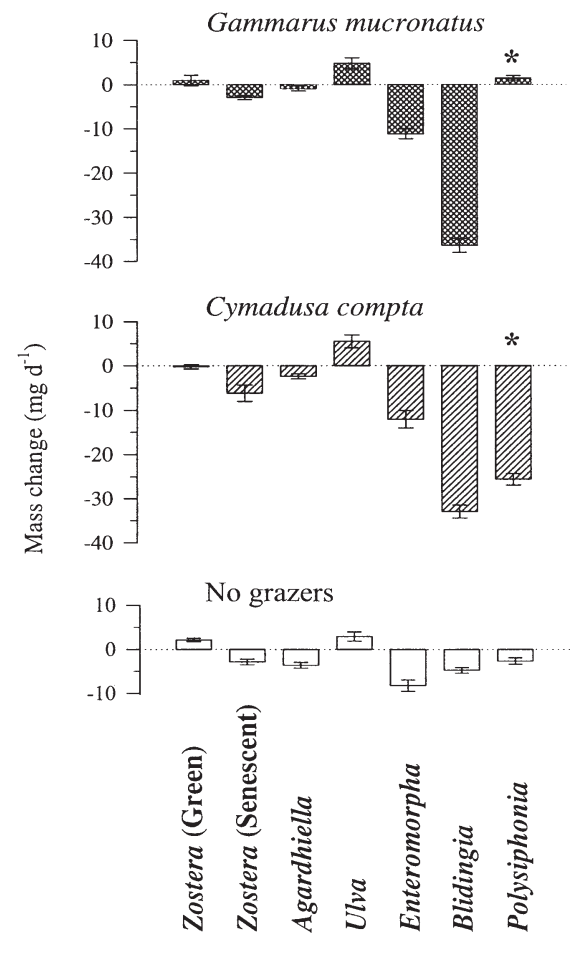

Fig. 1. Results of laboratory choice assays measuring the relative feeding rates (mean $\pm 1 \mathrm{SE}$ ) of Gammarus mucronatus and the ampithoid Cymadusa compta on eelgrass and 5 macroalgae common in local seagrass beds. Assays were conducted simultaneously for both grazers and the no-grazer control. $\mathrm{n}=20$ for each bar. ${ }^{*}$ Polysiphonia was the only plant eaten at significantly different rates by the 2 grazers (Bonferronicorrected $\mathrm{p}<0.05, t$-tests)

that was double the initial abundance in any other treatment. The similarity among treatments in final amphipod biomass also contrasted with the variation in final abundance (Fig. 2A, Table 1).

The second line of evidence for a common carrying capacity comes from a direct test for interspecific competition: discrete population growth rates of both Gammarus mucronatus and ampithoids were strongly and significantly reduced when the other grazer was present (Fig. 3, Table 2). Thus, population growth rates and final densities of both grazer taxa were reduced significantly when the other grazer was present, presumably as a result of exploitative competition for limited algal food. Final abundances and biomasses of the 2 amphipod taxa were roughly similar in the treatments where both were present (Fig. 2).

The presence of interspecific competitors also influenced size frequency
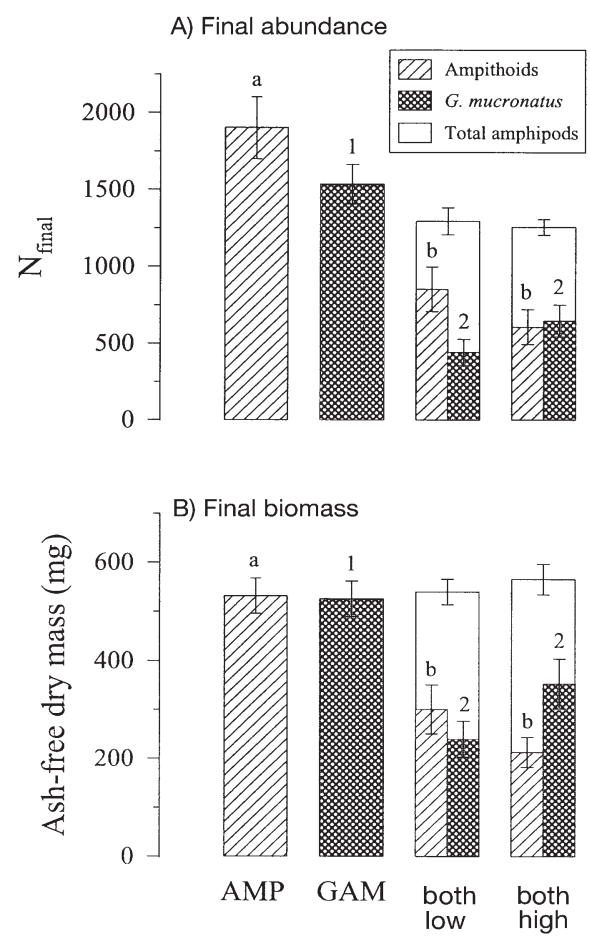

Fig. 2. (A) Mean $\pm 1 \mathrm{SE}$ final abundances $\left(\mathrm{N}_{\text {final }}\right)$ and (B) estimated biomasses of amphipods in the absence and presence of potential competitors. Bars sharing the same letter represent treatments in which final ampithoid abundance did not differ significantly at $\alpha=0.05$ (Ryan's $Q$-tests following ANOVA, see Table 2); bars sharing the same number represent treatments in which final Gammarus mucronatus (GAM) abundance did not differ significantly. The wider, open bar in the 'both low' and 'both high' treatments represents the combined data for both taxa (see Table 1); the component filled bars represent data for the individual taxa. $\mathrm{n}=7$ for each treatment

distributions of amphipods (Fig. 4). Compared with the respective single-taxon treatments, both amphipod taxa showed an increase in frequency of the larger size classes $(2.00 \mathrm{~mm}$ sieve size for ampithoids, 2.00 and $2.8 \mathrm{~mm}$ sieve sizes for Gammarus mucronatus) when

Table 1. Results of ANOVAs testing differences among grazer treatments in the final aggregate abundance and ash-free dry biomass of amphipods (both taxa combined, Fig. 2). Both response variables were initially analyzed using randomized block ANOVAs; in the case of final biomass the block factor was nonsignificant $(\mathrm{p}>0.25)$, so it was subsequently ignored and the data were reanalyzed using 1-factor ANOVA, following recommendations of Winer et al. (1991). ${ }^{*} \mathrm{p} \leq 0.05$

\begin{tabular}{|lrrrrrrrrr|}
\hline \multirow{2}{*}{ Source } & \multicolumn{3}{c}{ Total abundance } & \multicolumn{4}{c|}{ Total biomass } \\
& df & MS & $F$ & p & df & MS & $F$ & $\mathrm{p}$ \\
\hline Block & 6 & 0.0634 & 1.5 & 0.22 & & & & \\
Treatment & 3 & 0.2267 & 5.5 & $0.0074^{*}$ & 3 & 1400 & 0.2 & 0.90 \\
$\begin{array}{l}\text { Block } \times \text { Treatment } \\
\text { Error }\end{array}$ & 18 & 0.0413 & & & & & & \\
& & & & & 24 & 7635 & & \\
\hline
\end{tabular}




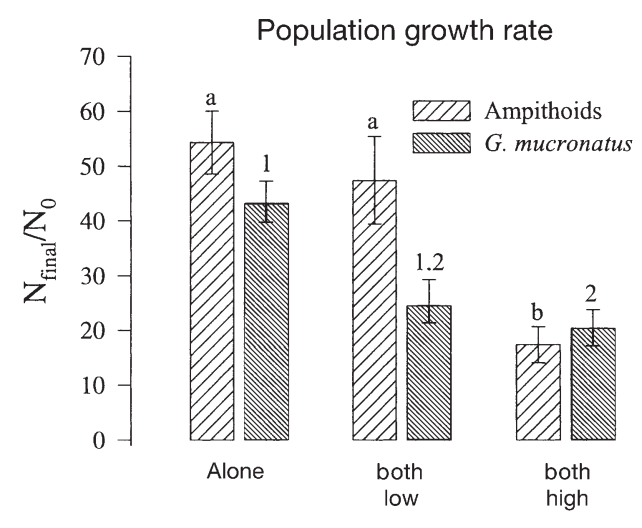

Fig. 3. Mean $\pm 1 \mathrm{SE}$ discrete population growth rates of amphipods in the absence and presence of potential competitors. $\mathrm{N}_{0}$ and $\mathrm{N}_{\text {final }}$ are amphipod abundances at the beginning and end of the experiment, respectively. Symbols and analysis are as in Fig. 2. See Table 2 for statistical analysis

competitors were present at high density. These shifts in size distribution suggest that interspecific competition favored larger individuals. Similarly, for $G$. mucronatus, the smallest size class also declined substantially when ampithoids were present (Fig. 4). Cannibalism has been reported in Gammarus species (MacNeil et al. 1999) and may have contributed to the reduction in smaller size classes, although this would not explain why the effect was greater in the presence of an interspecific competitor. Thus, the effects of competition may have fallen disproportionately on new recruits, potentially explaining the reduced population growth in the presence of competitors (Fig. 3). The shift toward larger size in treatments with competitors also explains why total amphipod biomass was constant across treatments whereas total abundance was substantially lower in competition treatments (Fig. 2, Table 1).
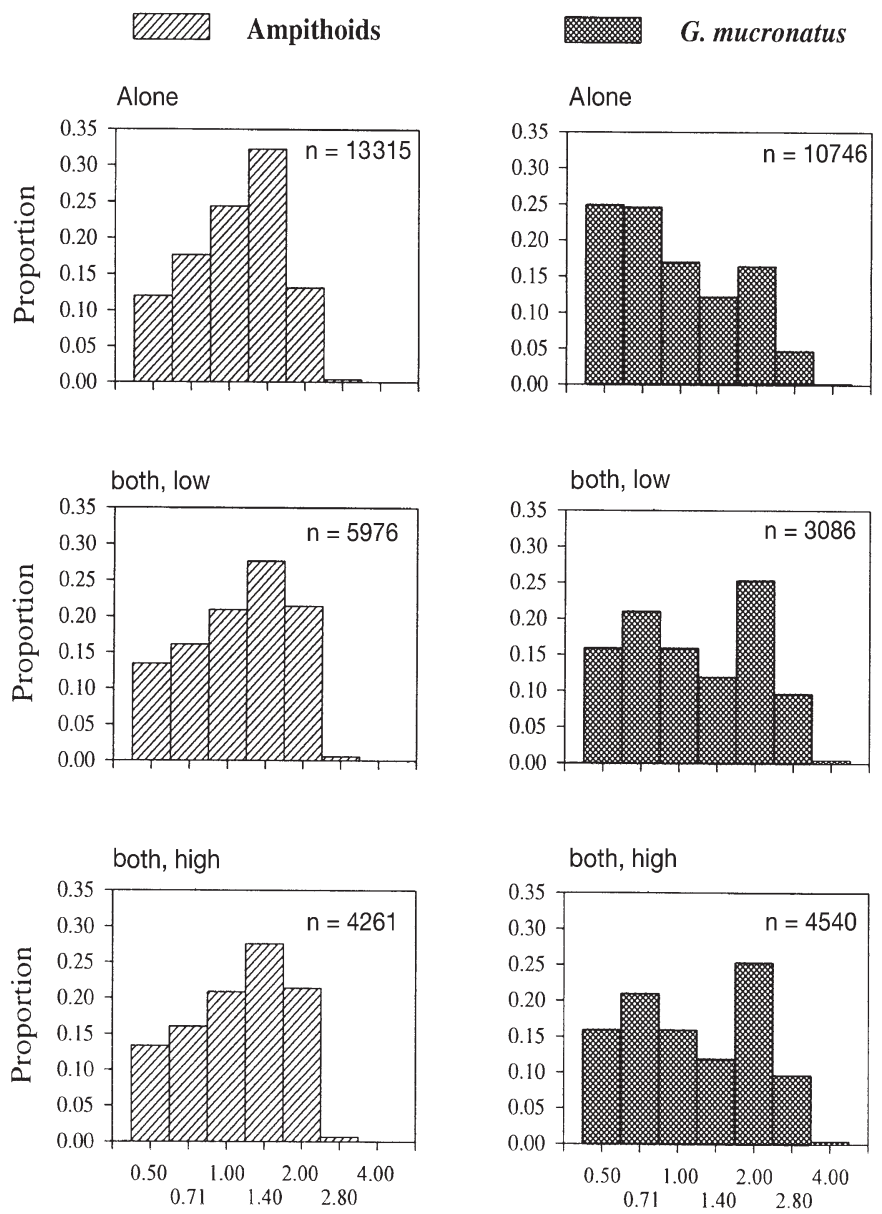

Sieve size class

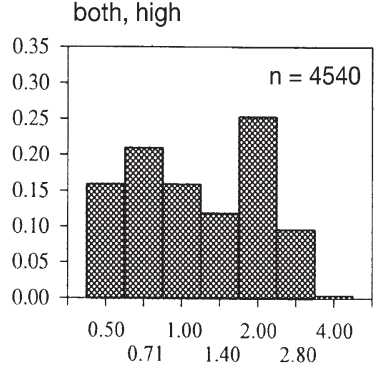

Sieve size class

Fig. 4. Size frequency distributions of amphipods in the absence and presence of potential competitors. Each size class corresponds to the mesh size $(\mathrm{mm})$ of sieve on which specimens were retained, when passed through a nested series of sieves (see 'Materials and methods'). Total number of amphipods is shown for each panel

Table 2. Results of ANOVAs testing differences between amphipod species and among treatments (single grazer taxon, both low and both high) in the final abundance, final ash-free dry biomass and population growth rate $\left(\mathrm{N}_{\text {final }} / \mathrm{N}_{0}\right)$ of amphipods. Block factors were non-significant $(p>0.25$ ) for final biomass and population growth rate, so these variables were reanalyzed as 2 -factor ANOVAs, shown here. ${ }^{*} \mathrm{p}<0.05$

\begin{tabular}{|c|c|c|c|c|c|c|c|c|c|c|c|c|}
\hline \multirow[t]{2}{*}{ Source } & \multicolumn{4}{|c|}{ Final abundance } & \multicolumn{4}{|c|}{ Final biomass } & \multicolumn{4}{|c|}{ Population growth rate } \\
\hline & $\mathrm{df}$ & MS & $F$ & $\mathrm{p}$ & $\mathrm{df}$ & MS & $F$ & $\mathrm{p}$ & $\mathrm{df}$ & MS & $F$ & $\mathrm{p}$ \\
\hline Block & 6 & 114172 & 1.7 & 0.211 & & & & & & & & \\
\hline Treatment & 2 & 5451259 & 42.8 & $0.0001^{*}$ & 2 & 298286 & 25.6 & $0.0001^{*}$ & 2 & 3138 & 16.9 & $0.0001^{*}$ \\
\hline Species & 1 & 638867 & 5.0 & 0.154 & 1 & 6163 & 0.5 & 0.472 & 1 & 1128 & 6.1 & $0.019^{*}$ \\
\hline Treatment $\times$ Species & 2 & 217342 & 3.2 & 0.078 & 2 & 37824 & 3.3 & 0.051 & 2 & 592 & 3.2 & 0.054 \\
\hline Block $\times$ Species & 6 & 240377 & & & & & & & & & & \\
\hline Block $\times$ Treatment & 12 & 136282 & & & & & & & & & & \\
\hline Block $\times$ Treatment $\times$ Species & 12 & 68339 & & & & & & & & & & \\
\hline Error & & & & & 36 & 11649 & & & 36 & 186 & & \\
\hline
\end{tabular}




\section{Grazer impacts on the eelgrass fouling assemblage}

Gammarus mucronatus and ampithoids differed substantially in their impacts on the assemblage of epiphytes, sessile invertebrates and detritus that accumulated on eelgrass during the experiment (Fig. 5). When first measured at $2 \mathrm{wk}$, epiphyte biomass (as chl a) was already very low in treatments containing ampithoids, with a strong but marginally non-significant $(0.05<\mathrm{p}<$ $0.10)$ trend toward higher biomass in grazer-free controls. Variance among replicates was high at this time as a result of the patchy development of diatom tufts in controls and Polysiphonia harveyi thalli in the $G$. mucronatus treatment.

By the end of the experiment, total mass of fouling material and epiphyte biomass showed similar patterns, being high in the grazer-free control and Gammarus mucronatus treatments but virtually absent in all 3 treatments that contained ampithoids $(\mathrm{p}<0.001$ for both fouling and epiphytic chl a, Friedman's test, Fig. 5). The similarity between G. mucronatus and grazer-free treatments in these bulk measurements, however, obscures marked differences in the composition of the fouling assemblage in these 2 treatments. Whereas grazer-free treatments were heavily fouled with periphyton, associated detritus and sediment, $G$. mucronatus virtually eliminated this periphytic material and allowed the filamentous red alga Polysiphonia harveyi to flourish, presumably by releasing it from competition with periphyton. Indeed, P. harveyi, which was rare in other treatments, dominated the G. mucronatus treatment, achieving a dry biomass 8 times higher than in any other treatment, a significant difference ( $p<0.001$, Friedman's test, Fig. 5). Ampithoids, in contrast, entirely eliminated $P$. harveyi. The other dominant fouling macroorganism, the tunicate Molgula manhattensis, reached high biomass in the absence of grazers but was significantly depressed by both amphipod taxa, particularly ampithoids (Fig. 5, Table 3). There was a significant block effect on Molgula biomass (Table 3), indicating that some aspect of stocking schedule or location of the microcosms (both incorporated in the block effect in our design) affected this variable; nevertheless, the effect of grazer treatment was much stronger.

\section{Grazer impacts on eelgrass}

Whereas grazers dramatically influenced the fouling assemblages, they had no impact on eelgrass standing biomass (above-ground: $F_{4,24}=0.94$, $\mathrm{p}=0.46$, randomized-block ANOVA; below-ground: $F_{4,30}=2.12, \mathrm{p}=0.103$,

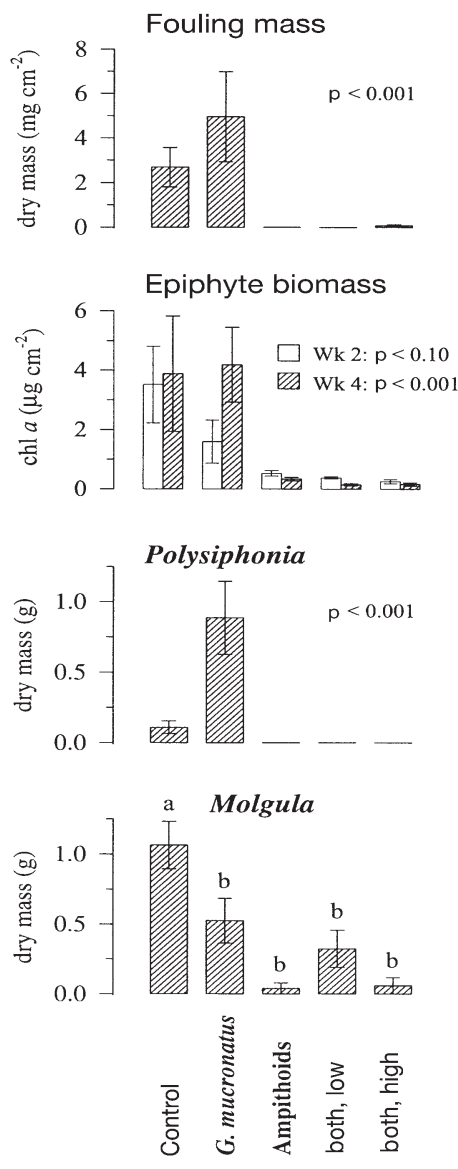

Fig. 5. Mean $\pm 1 \mathrm{SE}$ final masses of total fouling material, epiphytes (as chlorophyll a [chl a]) and the dominant fouling macroorganisms in different grazer treatments. Epiphytic chl a was measured at Weeks 2 and 4; other variables were measured only at the end of the experiment (Week 4). P values in the top 3 panels are from Friedman's tests. Bars sharing the same letter in the Molgula panel do not differ significantly at $\alpha=0.05$ (ANOVA followed by Ryan's $Q$-test)

1-way ANOVA, Fig. 6). In contrast, ampithoids did influence the production of eelgrass macrodetritus. The mass of fragmented eelgrass collected floating on the water surface differed significantly among treatments (Fig. 6, Table 3), averaging 4 to 5 times higher in

Table 3. Results of randomized block ANOVAs testing differences among grazer treatments in the final dry biomass of the fouling tunicate Molgula manhattensis

(Fig. 5) and of detached floating eelgrass debris (Fig. 6). ${ }^{*} \mathrm{p} \leq 0.05$

\begin{tabular}{|c|c|c|c|c|c|c|c|c|}
\hline \multirow[t]{2}{*}{ Source } & \multicolumn{4}{|c|}{$\begin{array}{c}\text { Molgula manhattensis } \\
\text { biomass }\end{array}$} & \multicolumn{4}{|c|}{ Detached eelgrass } \\
\hline & df & MS & $F$ & $\mathrm{p}$ & df & MS & $F$ & $\mathrm{p}$ \\
\hline Block & 6 & 0.235 & 3.1 & $0.021^{*}$ & 6 & 0.0241 & 4.2 & $0.0049^{*}$ \\
\hline Treatment & 4 & 1.243 & 16.4 & $0.0001^{*}$ & 4 & 0.0357 & 6.2 & $0.0014^{*}$ \\
\hline Block $\times$ Treatment & 24 & 0.076 & & & 24 & 0.0057 & & \\
\hline
\end{tabular}



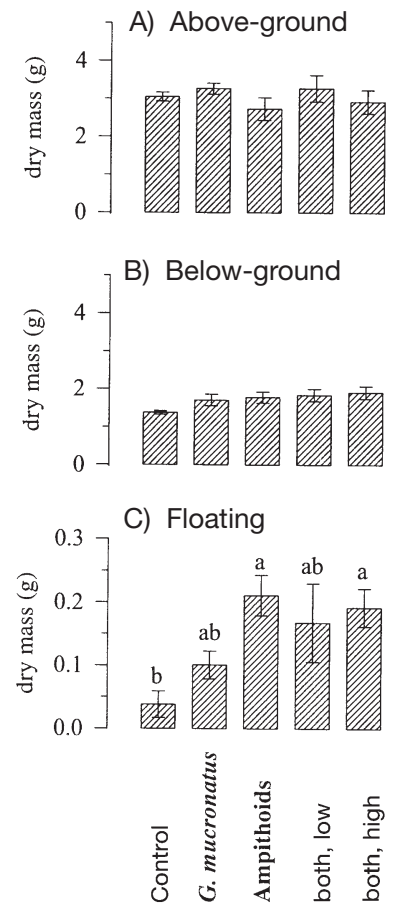

Fig. 6. Mean \pm 1 SE final biomasses of eelgrass (A) above ground, (B) below ground and (C) as floating, detached fragments, in different grazer treatments. Note different scale for (C). See Fig. 5 for symbols and Table 3 for statistical analysis

treatments with ampithoids than in the grazer-free control, with the Gammarus mucronatus treatment being intermediate but not significantly different from the others. The floating eelgrass fragments bore obvious grazing scars that presumably resulted from ampithoids grazing on eelgrass after epiphytes had been depleted.

\section{Field biomass of mesograzers}

In October 1999, estimated total biomass of mesograzers at our field site averaged $0.11 \pm 0.01 \mathrm{mg}$ AFDM $\mathrm{cm}^{-2}$ eelgrass, with a maximum of $0.20 \mathrm{mg} \mathrm{cm}^{-2}$. Standardized to unit bottom area, this corresponds to an estimated average mesograzer biomass of $6.3 \pm 0.5 \mathrm{~g}$ AFDM m ${ }^{-2}$. By comparison, at the end of the microcosm experiment, estimated amphipod biomass per unit surface area of habitat, including both eelgrass and container walls, averaged 0.12 to $0.14 \mathrm{mg} \mathrm{cm}{ }^{-2}$ across the grazer treatments. The microcosm estimates were about 4-fold higher when tank walls were excluded from the calculations, amphipod AFDM averaging 0.39 to $0.50 \mathrm{mg} \mathrm{cm}{ }^{-2}$ across grazer treatments. These microcosm estimates are equivalent to 9.5 to $9.9 \mathrm{~g}$ amphipod AFDM m ${ }^{-2}$ bottom.

\section{DISCUSSION}

\section{Mesograzer impacts on benthic community structure}

Grazing by the 2 amphipod taxa we studied produced strong but markedly different impacts on eelgrass fouling assemblages: (1) eelgrass in the absence of grazers accumulated a thick coating of periphyton, detritus and tunicates; whereas (2) eelgrass under the influence of Gammarus mucronatus was generally clean of periphyton but fouled by heavy growth of Polysiphonia harveyi; (3) eelgrass exposed to ampithoids was essentially free of all fouling organisms and sediment (Fig. 5). It is widely appreciated that mesograzer feeding on periphyton and epiphytic algae can potentially enhance the survival and growth of seagrasses and other macrophytes (Orth \& van Montfrans 1984, van Montfrans et al. 1984, Bell 1991, Brawley 1992, Jernakoff et al. 1996). Less generally recognized is the diversity in feeding biology among mesograzers and its potential importance for understanding the community structure and dynamics of marine vegetation. The assemblages of small grazing and detritivorous invertebrates that inhabit marine plants have frequently been treated as a relatively homogeneous group, with similar ecology and feeding biology (Steneck \& Watling 1982, Edgar 1990a, Bell 1991). Given that our experiment focused on amphipod crustacean taxa of similar body size, the differences in fouling assemblages that developed under the influence of $G$. mucronatus compared with ampithoid amphipods (Fig. 5) were unexpected. As G. mucronatus dominates local mesograzer communities in spring, whereas ampithoids are most abundant in fall (Duffy et al. 2001, unpubl. data), the divergent impacts we documented might be realized in the field as well.

Also unexpected was the strong reduction in tunicate abundance by amphipods, especially ampithoids (Fig. 5), which are primarily herbivorous and perform best on diets of algae in the laboratory (Cruz-Rivera \& Hay 2000). Amphipods presumably affected tunicates at or shortly after settlement of their larvae, although whether amphipods actually eat young recruits or remove them through physical disturbance is unknown. Similarly strong impacts of small, inconspicuous gastropods on recruitment of sessile invertebrates have been shown experimentally (Osman et al. 1992, Osman \& Whitlach 1995). Interestingly, Molgula manhattensis is uncommon on eelgrass in the field (where mesograzers are generally abundant), whereas it sometimes 'blooms' on eelgrass in our microcosms during summer if mesograzers are at low abundance. If such effects of mesograzers on sessile invertebrates are common, it suggests that their impacts on benthic community organization may be much more pervasive than 
presently recognized, extending beyond epiphytes (Jernakoff et al. 1996) and macroalgae (Duffy \& Hay $2000)$ to the invertebrates that dominate fouling communities throughout the world.

Despite their dramatic impacts on mass and composition of fouling material, grazers had no significant impact on growth of eelgrass. This is probably because the experiment was relatively short (4 wk) and was conducted during the summer, when eelgrass shoots are beginning to senesce (Wetzel \& Penhale 1983). Over longer periods of time, particularly during spring or fall, we suspect that the divergent fouling assemblages produced by these grazers would have significantly different influences on host macrophyte fitness. In particular, although both the Gammarus mucronatus and grazer-free control treatments accumulated large and similar biomass of fouling material, the crust of periphyton and sediment accumulated in the control is likely to be much more detrimental to eelgrass than the similar biomass of Polysiphonia harveyi in the $G$. mucronatus treatment. Whereas periphyton is more or less opaque and coats much of the macrophyte's blade surface, presumably reducing light substantially, $P$. harveyi grew as tufts of filamentous branches attached by a small holdfast to the eelgrass blade and probably had little impact on light attenuation. The enhancement of $P$. harveyi by $G$. mucronatus may also indirectly increase recruitment and abundance of mesograzers, as finely branched filamentous algae are an important habitat for small stages of epifaunal species (Edgar 1983, Hacker \& Steneck 1990). Finally, reduction of tunicate biomass by both amphipod taxa in our experiment likely would affect macrophyte fitness eventually as adult tunicates are large, and heavy accumulations can weigh eelgrass blades down to the sediment surface.

\section{Resource limitation of mesograzer populations?}

The 2 amphipod taxa in our experiment were clearly limited by a common resource, presumably periphyton production, as evidenced by the convergence of all grazer treatments on a similar total biomass (Fig. 2B) and the clear effects of interspecific competition on population growth (Fig. 3). Are these amphipods resource limited in the field as well? Because our study did not include predators, we cannot address this issue directly. Nevertheless, 2 lines of evidence are consistent with such bottom-up regulation in Chesapeake Bay eelgrass beds. First, mesograzer abundances in our area are generally highest in late summer, when temperature and insolation (and, thus, potential primary production) are also highest. Since fish predators in Chesapeake Bay are also most abundant and largest during summer (Orth \& Heck 1980), this pattern is the opposite of what would be expected under top-down control, and what is observed in North Carolina eelgrass beds, where omnivorous pinfish are abundant (Adams 1976) and epifaunal amphipod populations decline rapidly in late spring (Nelson 1979, Duffy \& Hay 1991b, 1994). Orth \& Heck (1980) also noted the much higher abundance of epifauna in Chesapeake Bay than in more southerly eelgrass beds and suggested that the absence of omnivorous pinfish Lagodon rhomboides in Chesapeake Bay may release epifaunal crustaceans from the heavy predation they experience southward.

Second, bottom-up regulation of epifauna in our system is supported by the evidence for resource limitation. When standardized to total available habitat area (including tank walls), estimated biomass of mesograzers in our experiment $\left(0.12\right.$ to $0.14 \mathrm{mg} \mathrm{cm}^{-2}$, measured in July) was remarkably similar to that at our field site (0.11 $\pm 0.01 \mathrm{mg}$ AFDM cm${ }^{-2}$, measured in October), suggesting that predation does not strongly depress mesograzer biomass at this site. This conclusion is complicated somewhat by inclusion in the calculation of tank walls, a habitat that is not present in the field. Ignoring the tank walls yields roughly 4 -fold higher estimates ( 0.39 to $0.50 \mathrm{mg} \mathrm{cm}^{-2}$ ) of mesograzer biomass per unit habitat (i.e. eelgrass blade surface) area. Yet the latter calculations are also biased in that periphyton clearly grew on the walls and amphipods clearly used this habitat; thus, estimates ignoring the area of walls artificially inflate the area-standardized grazer densities (see also Chen et al. 1997 for discussion of similar effects in pelagic mesocosms). In any case, although these calculations are obviously preliminary, the evidence for bottom-up control of mesograzer biomass in our system is consistent with experiments and energetic calculations (Edgar 1990a,b, 1993) suggesting that epifaunal production in many shallow marine habitats is limited by plant production rather than predation. Finally, resource limitation of mesograzer abundance at our site is also suggested by the virtual absence of visible epiphyte accumulation on eelgrass during much of the year.

Our results may offer a partial reconciliation between the view of mesograzers as a homogeneous functional group (Edgar 1990a, 1993, Bell 1991) and the evidence of diverse and selective feeding biology among taxa (Kitting 1984, Duffy 1990, Duffy \& Hay 1991a, Pavia et al. 1999), underscoring that the question of functional equivalence depends on the particular response variable of interest. In terms of energy flow and trophodynamics, the 2 amphipod taxa we studied appear equivalent: they competed for the same resource, both cropped all visible periphyton in the experiments, reached nearly identical final biomasses 
and were indistinguishable in population growth rates. At the community level, however, grazing by Gammarus mucronatus and ampithoids produced substantially different fouling assemblages. These results underscore the important point, emphasized by Paine (1980), that there is no consistent relationship between an organism's contribution to energy flow and its influence on community structure. The species specificity of mesograzer feeding preferences and impacts documented in this and other recent studies (Duffy \& Hay $1994,2000)$ are likely important contributors to the variability in macrophyte-epiphyte-grazer interactions emphasized in recent reviews (Orth 1992, Jernakoff et al. 1996), as are differences among species in feeding and population growth rates, which lead to substantial differences among species in secondary production (Duffy et al. 2001). The common 'black-box' approach to mesograzer ecology may obscure important processes in the trophic dynamics and community organization of vegetated marine ecosystems.

Acknowledgements. We are grateful to T. Macdonald for help in designing and setting up the experiment, M. Mitchell for collecting the final samples and help with chlorophyll analyses, B. Lilley for processing field samples, P. Heidemann and L. Sanderson for advice and critical reading of earlier versions of the manuscript, K. Moore for use of the area meter, B. Neikirk for advice on chlorophyll analysis, 2 anonymous reviewers for helpful comments on the manuscript, and the Crustacean Ecology and SAV groups at VIMS for generously sharing facilities and equipment. This research was supported by NSF (OCE 95-21184) and is VIMS Contribution No. 2424

\section{LITERATURE CITED}

Adams SM (1976) The ecology of eelgrass (Zostera marina L.) fish communities. I. Structural analysis. J Exp Mar Biol Ecol 22:269-291

Bell SS (1991) Amphipods as insect equivalents? An alternative view. Ecology 72:350-354

Brawley SH (1992) Mesoherbivores. In: John DM, Hawkins SJ, Price JH (eds) Plant-animal interactions in the marine benthos. Clarendon Press, Oxford, p 253-263

Chen CC, Petersen JR, Kemp WM (1997) Spatial and temporal scaling of periphyton growth on walls of estuarine mesocosms. Mar Ecol Prog Ser 155:1-15

Cruz-Rivera E, Hay ME (2000) The effects of diet mixing on consumer fitness: macroalgae, epiphytes, and animal matter as food for marine amphipods. Oecologia 123:252-264

Day RW, Quinn GP (1989) Comparisons of treatments after an analysis of variance. Ecol Monogr 59:433-463

Duffy JE (1990) Amphipods on seaweeds: partners or pests? Oecologia 83:267-276

Duffy JE, Hay ME (1991a) Food and shelter as determinants of food choice by an herbivorous marine amphipod. Ecology 72:1286-1298

Duffy JE, Hay ME (1991b) Amphipods are not all created equal: a reply to Bell. Ecology 72:354-358

Duffy JE, Hay ME (1994) Herbivore resistance to seaweed chemical defense: the roles of mobility and predation risk Ecology 75:1304-1319

Duffy JE, Hay ME (2000) Strong impacts of grazing amphipods on the organization of a benthic community. Ecol Monogr 70:237-263

Duffy JE, Macdonald KS, Rhode JM, Parker JD (2001) Grazer diversity, functional redundancy, and productivity in seagrass beds: an experimental test. Ecology 82:2417-2434

Edgar GJ (1983) The ecology of southeast Tasmanian phytal animal communities. I. Spatial organization on a local scale. J Exp Mar Biol Ecol 70:129-157

Edgar GJ (1990a) Population regulation, population dynamics and competition amongst mobile epifauna associated with seagrass. J Exp Mar Biol Ecol 144:205-234

Edgar GJ (1990b) The use of the size structure of benthic macrofaunal communities to estimate faunal biomass and secondary production. J Exp Mar Biol Ecol 137:195-214

Edgar GJ (1993) Measurement of the carrying capacity of benthic habitats using a metabolic-rate based index. Oecologia 95:115-121

Edgar GJ, Aoki M (1993) Resource limitation and fish predation: their importance to mobile epifauna associated with Japanese Sargassum. Oecologia 95:122-133

Edgar GJ, Shaw C (1995) The production and trophic ecology of shallow-water fish assemblages in southern Australia. III. General relationships between sediments, seagrasses, invertebrates and fishes. J Exp Mar Biol Ecol 194:107-131

Hacker SD, Steneck RS (1990) Habitat architecture and the abundance and body-size-dependent habitat selection of a phytal amphipod. Ecology 71:2269-2285

Hootsmans MJM, Vermaat JE (1985) The effect of periphyton-grazing by three epifaunal species on the growth of Zostera marina L. under experimental conditions. Aquat Bot 22:83-88

Howard RK, Short FT (1986) Seagrass growth and survivorship under the influence of epiphyte grazers. Aquat Bot 24:287-302

Jernakoff P, Nielsen J (1997) The relative importance of amphipod and gastropod grazers in Posidonia sinuosa meadows. Aquat Bot 56:183-202

Jernakoff P, Brearley A, Nielsen J (1996) Factors affecting grazer-epiphyte interactions in temperate seagrass meadows. Oceanogr Mar Biol Annu Rev 34:109-162

Jones CG, Lawton JH, Shachak M (1994) Organisms as ecosystem engineers. Oikos 69:373-386

Kikuchi T (1974) Japanese contributions on consumer ecology in eelgrass (Zostera marina L.) beds, with special reference to trophic relationships and resources in inshore fisheries. Aquaculture 4:145-160

Kitting CL (1984) Selectivity by dense populations of small invertebrates foraging among seagrass blade surfaces. Estuaries 7:276-288

Klumpp DW, Howard RK, Pollard DA (1989) Trophodynamics and nutritional ecology of seagrass communities. In: Larkum AWD, McComb AJ, Shepherd SA (eds) Biology of seagrasses. Elsevier, Amsterdam, p 394-457

MacNeil C, Dick JTA, Elwood RW (1999) The dynamics of predation on Gammarus spp. (Crustacea: Amphipoda). Biol Rev 74:375-395

Nagle JS (1968) Distribution of the epibiota of macroepibenthic plants. Contrib Mar Sci Univ Texas 13:105-144

Neckles HA, Wetzel RL, Orth RJ (1993) Relative effects of nutrient enrichment and grazing on epiphyte-macrophyte (Zostera marina L.) dynamics. Oecologia 93:285-295

Nelson WG (1979) An analysis of structural pattern in an eelgrass (Zostera marina L.) amphipod community. J Exp Mar Biol Ecol 39:231-264 
Nelson WG (1980) A comparative study of amphipods in seagrasses from Florida to Nova Scotia. Bull Mar Sci 30: 80-89

Newman JA, Bergelson J, Grafen A (1997) Blocking factors and hypothesis tests in ecology: is your statistics text wrong? Ecology 78:1312-1320

Orth RJ (1992) A perspective on plant-animal interactions in seagrasses: physical and biological determinants influencing plant and animal distributions. In: John DM, Hawkins SJ, Price JH (eds) Plant-animal interactions in the marine benthos. Clarendon Press, Oxford, p 147-164

Orth RJ, Heck KL (1980) Structural components of eelgrass (Zostera marina) meadows in the lower Chesapeake Bay-fishes. Estuaries 3:278-288

Orth RJ, van Montfrans J (1984) Epiphyte-seagrass relationships with an emphasis on the role of micrograzing: a review. Aquat Bot 18:43-69

Orth RJ, Moore KA (1986) Seasonal and year-to-year variation in the growth of Zostera marina L. (eelgrass) in the lower Chesapeake Bay. Aquat Bot 24:335-341

Osman RW, Whitlatch RB (1995) Predation on early ontogenetic life stages and its effect on recruitment into a marine epifaunal community. Mar Ecol Prog Ser 117:111-126

Osman RW, Whitlatch RB, Malatesta RJ (1992) Potential role of micro-predators in determining recruitment into a marine community. Mar Ecol Prog Ser 83:35-43

Paine RT (1980) Food webs: linkage, interaction strength and community infrastructure. J Anim Ecol 49:667-685

Parker JD, Duffy JE, Orth RJ (2001) Experimental tests of plant diversity effects on epifaunal diversity and production in a temperate seagrass bed. Mar Ecol Prog Ser 224

Parsons TR, Maita Y, Lalli CM (1984) A manual of chemical and biological methods for seawater analysis. Pergamon Press, Elmsford

Editorial responsibility: Kenneth Heck (Contributing Editor), Dauphin Island, Alabama, USA
Pavia H, Carr H, Åberg P (1999) Habitat and feeding preferences of crustacean mesoherbivores inhabiting the brown seaweed Ascophyllum nodosum (L.) Le Jol. and its epiphytic macroalgae. J Exp Mar Biol Ecol 236:15-32

Rice WR (1989) Analyzing tables of statistical tests. Evolution 43:223-225

Robertson AI, Mann KH (1982) Population dynamics and life history adaptations of Littorina neglecta Bean in an eelgrass meadow (Zostera marina L.) in Nova Scotia. J Exp Mar Biol Ecol 63:151-171

Schneider FI, Mann KH (1991) Species specific relationships of invertebrates to vegetation in a seagrass bed. I. Correlational studies. J Exp Mar Biol Ecol 145:101-117

Sokal RR, Rohlf FJ (1981) Biometry. Freeman, San Francisco

Steneck RS, Watling L (1982) Feeding capabilities and limitations of herbivorous molluscs: a functional group approach. Mar Biol 68:299-319

Taylor RB (1998) Density, biomass and productivity of animals in four subtidal rocky reef habitats: the importance of small mobile invertebrates. Mar Ecol Prog Ser 172:37-51

Valentine JF, Heck KL Jr (1999) Seagrass herbivory: Evidence for the continued grazing of marine grasses. Mar Ecol Prog Ser 176:291-302

van Montfrans J, Wetzel RL, Orth RJ (1984) Epiphyte-grazer relationships in seagrass meadows: consequences for seagrass growth and production. Estuaries 7:289-309

Wetzel RL, Penhale PA (1983) Production ecology of seagrass communities in the lower Chesapeake Bay. Mar Technol Soc J 17:22-31

Winer BJ, Brown DR, Michels KM (1991) Statistical principles in experimental design, 3rd edn. McGraw-Hill, New York

Zimmerman R, Gibson R, Harrington J (1979) Herbivory and detritivory among gammaridean amphipods from a Florida seagrass community. Mar Biol 54:41-47

Submitted: August 18, 2000; Accepted: February 20, 2001

Proofs received from author(s): October 30, 2001 